\title{
An Overall Trend of Headache Remission during COVID-19 Pandemic for Chinese Patients with Pre- existing Headache Highlights the Role of Family Supports
}

\section{Qiaoyu Gong}

Renmin Hospital of Wuhan University: Wuhan University Renmin Hospital

Shuping Liu

Renmin Hospital of Wuhan University: Wuhan University Renmin Hospital

Ruiting Li

Renmin Hospital of Wuhan University: Wuhan University Renmin Hospital

Lihua Yao

Renmin Hospital of Wuhan University: Wuhan University Renmin Hospital

Zheman xiao ( $\boldsymbol{D}$ zmxiao@whu.edu.cn )

Wuhan University Renmin Hospital

Research article

Keywords: COVID-19, impact, headache, remission, family support

Posted Date: October 28th, 2020

DOl: https://doi.org/10.21203/rs.3.rs-93426/v1

License: (1) (1) This work is licensed under a Creative Commons Attribution 4.0 International License.

Read Full License 


\section{Abstract}

Background: Impact of COVID-19 pandemic on Chinese patients with pre-existing headache remains unclear. The present study investigated the impact of COVID-19 pandemic on headache patients in China.

Methods: A survey was conducted through an online survey platform from June 6, 2020. Demographic characteristics, PHQ-9 scores, ISI scores, COVID-19 questionnaires and headache profile section were included in the online questionnaires.

Results: Eventually a total of 15,000 participants from China completed the online questionnaire. Among them, 2806 participants $(18.71 \%)$ had preexisting headache disorders. Our analysis showed a reality of those participants with remission of headache duration ( $3.414 \pm 6.859$ vs $4.033 \pm 7.325, P=0.000)$, headache days per month ( $1.788 \pm 2.989$ vs $2.092 \pm 3.694, P=0.000)$, and headache intensity $(4.110 \pm 1.609$ vs $4.290 \pm 1.680, P=0.000)$, during COVID-19. Smoking ( $O R=1.397,95 \% \mathrm{Cl} 1.090$ to $1.790, P=0.008)$ and getting support from family members during the social isolation $(\mathrm{OR}=1.656,95 \% \mathrm{Cl} 1.075$ to 2.550 , $\mathrm{P}=0.022)$ were the independent factors of remission in headache duration. Education level $(O R=1.478$, $95 \% \mathrm{Cl} 1.103$ to $1.980, \mathrm{P}=0.009)$ and having relative or acquaintance got COVID-19 (OR=0.643, 95\% $\mathrm{Cl}$ 0.458 to $0.902, \mathrm{P}=0.011$ ) were the independent factors of remission in headache severity. And participants living in Wuhan area, having COVID-19 symptoms or COVID-19 diagnosis and having relative or acquaintance got COVID-19 are more likely to get headache deteriorated.

Conclusions: Participants presented an overall trend of headache remission during COVID-19. Family supports played an important role in headache remission.

\section{Background}

The coronavirus disease 2019 (COVID-19), first reported in Wuhan, China, has caused a large global pandemic, and is moving quickly via human-to-human transmission, droplets, or direct contact ${ }^{1}$. Currently, there are more than 32 million confirmed COVID-19 cases with more than 990,000 deaths worldwide. To minimize the exposure risk and prevent further spread of COVID-19, "social distancing" is advocated, to some extent, disrupting our normal life, work and medical care.

Typical symptoms of COVID-19 include fever, cough, and dyspnea ${ }^{2}$. Besides, neurological symptoms, such as dizziness and headache, have also been reported ${ }^{3}$. Almost $11-34 \%$ of the hospitalized COVID-19 patients present with headache ${ }^{4}$, but clinical features and underlying mechanisms of these headaches remain unclear. In a study from Singapore, most healthcare workers develop de novo personal protective equipment (PPE) -associated headaches or exacerbation of their preexisting headache disorders ${ }^{5}$. Headache patients, particularly migraine, are more vulnerable to such major stressful life events. Anxiety and stress caused by COVID-19 pandemic may aggravate a headache. Additionally, the COVID19 outbreak has drastically affected the medical care of patients with preexisting headache disorders ${ }^{5}$. First, due to the restriction of "social distancing", neurological physicians have had to adapt by replacing face- 
to-face visits with telemedicine visits ${ }^{6-9}$. On the one hand, telemedicine techniques bring dramatic benefit, to protect both patients and physicians while continuing to help headache patients receive medical care $^{6,8}$. On the other hand, patients with headache disorders, especially chronic migraine, usually rely on specific treatment, like Onabotulinumtoxin and pericranial nerve blocks ${ }^{10}$. Telemedicine limits the application of these treatments, and leads to deterioration in those patients ${ }^{7,9}$. In a word, it remains controversial whether the use of telemedicine can bring benefit for headache patients or not in the era of COVID-19. Second, headache medication like renin-angiotensin system (RAS) blockers and the nonsteroid anti-inflammatory drug (NSAID) ibuprofen, might be connected with an increased risk for COVID19 infection or a worse COVID19 clinical course ${ }^{11}$. However, conclusive evidence is lacking currently.

Global situation of COVID-19 pandemic is not optimistic. This is a particularly vulnerable time for patients with preexisting headache disorders, having aroused wide concern among headache specialist. It is imperative to understand the present situation of headache during COVID-19. To our knowledge, no research on headache patients in China during the COVID-19 pandemic has been reported. Thus, the present study aims to investigate the impact of COVID-19 pandemic on headache patients in China, and to further explore potential factors aggravating or relieving headache.

\section{Methods}

\section{Design and participants}

A survey was conducted through an online survey platform from June 6, 2020, completely voluntary and non-commercial. The questionnaire was anonymous, designed by the research team from Mental Health Center of Renmin Hospital of Wuhan University and School of Computing of Huazhong university of science and technology. All participants sign an informed consent before filling in the questionnaire, and can withdraw from the survey at any time. And all the online questionnaires were expressed in Chinese. Persons in the nation were encouraged to complete and submit the online questionnaires attentively on time. Participants completing all the online questionnaires were recruited.

\section{Variables and instruments}

Demographic characteristics

Demographic data included gender, age, education level, chronic disease history, smoking and drinking history.

Depressive symptoms

The Patient Health Questionnaire-9 (PHQ-9), a nine item questionnaire, was applied to assess depressive symptoms. Items are rated on a 4-point Likert-type scale, ranging from 0 (not at all) to 3 (nearly every day). Total score can range from 0 to 27 , with high scores meaning high depression ${ }^{12}$. 
Insomnia Severity Index (ISI), a brief self-report instrument, was applied to assess subjective sleep quality. The ISI comprises seven items. Each item is rated on a 4-point Likert-type scale, ranging from 0 to 3 , and the total score ranges from 0 to 28 . A higher score suggests more severe insomnia ${ }^{13}$.

COVID-19 questionnaires

COVID-19 questionnaires included having COVID-19 symptoms or COVID-19 diagnosis, having relative or acquaintance got COVID-19, getting support from family members, getting support from the outside world during the social isolation.

The Impact of Event Scale Revised (IES-R), a self-administered questionnaire, was applied to assess the psychological impact of COVID-19. The IES-R comprises 22 items, ranging from 0 to 4 , and the total score ranges from 0 to 88 . A higher score suggests more severe symptoms ${ }^{14}$.

The headache profile section

The headache profile section included items on history of preexisting headache disorders, characteristics of accompanying symptoms (nausea, vomiting, photophobia, phonophobia and osmophobia, aggravation by or causing avoidance of routine physical activity, lacrimation, rhinorrhea, conjunctival injection, and eye bilges, remission by massage), headache triggers (increased stress, sleep too short, sleep too long, menstruation, bright light, noise or special smell, special foods and alcohol), headache intensity/headache days per month/headache duration at baseline or during COVID-19, factors associated with headache during COVID-19(stress, sleep quality, changes in the law of life and decreased social interaction).

\section{Statistical Analysis}

Statistical analysis was performed with SPSS V.25.0 software (IBM, West Grove, Pennsylvania, USA). Categorical data were reported using proportions, while continuous data with means and standard deviations. The chi-square test was used to find out whether differences in proportions are significant. Mann-Whitney U test or the Wilcoxon Signed Rank Test was used to compare non-normally distributed data. Binary logistic regression was first performed to explore variables associated with headache relief. Then multivariate logistic regression analyses were performed to verify the independent influence factor associated with headache relief. A p-value $<0.05$ was considered to be statistically significant.

\section{Results}

Eventually a total of 15,000 participants from China completed the online questionnaire. Of which, 22 (0.13\%) respondents were diagnosed with COVID-19 infections. Overall, the majority of respondents were female (8569/15000, 57.13\%), aged 31-40 (6373/15000, 42.49\%), and well educated (11425/15000, $76.12 \%$ with at least a bachelor degree). Among them, 2806 participants $(18.71 \%)$ had preexisting headache disorders.

\section{The epidemiology of headache disorders in China}


Figure 1 shows demographic features of all headaches. Prevalence of headache peaked during adolescence (under 18 years old), followed by middle age (31-40 years). Headache was more prevalent in females $(20.57 \%)$ than in males $(16.22 \%)$.

Figure 2 presents characteristics of accompanying symptoms and headache triggers. 676 of 2806 participants (24.09\%) reported accompanying symptoms with nausea or vomiting; 531 (18.92\%) with photophobia, phonophobia or osmophobia; $641(18.92 \%)$ with aggravation by or causing avoidance of routine physical activity; 1555 (55.42\%) with remission by massage; and 294 (10.48\%) with lacrimation, rhinorrhea, conjunctival injection or eye bilges. Participants reported increased stress (48.43\%), sleep too short (69.60\%), sleep too long (8.62\%), menstruation (23.52\%), bright light, noise or special smell (13.79\%), special foods (2.99\%) and alcohol (7.34\%) as precipitating factor for headache attacks.

\section{Comparison of headache intensity, headache days per month, and headache duration at baseline and during COVID-19}

Table 1 presents comparison of headache intensity, duration, frequency (days per month), at baseline and during COVID-19. Our analysis showed a reality of those participants with remission of headache duration ( $3.414 \pm 6.859$ vs $4.033 \pm 7.325, P=0.000)$, headache days per month $(1.788 \pm 2.989$ vs $2.092 \pm$ $3.694, P=0.000)$, and headache intensity $(4.110 \pm 1.609$ vs $4.290 \pm 1.680, P=0.000)$, during COVID-19.

Table 1

Comparison of headache intensity, headache days per month, and headache duration at baseline and during COVID-19

\begin{tabular}{|llll|}
\hline variables & Baseline & During COVID-19 & P value \\
\hline Headache severity & $4.290 \pm 1.680$ & $4.110 \pm 1.609$ & $\mathbf{0 . 0 0 0}$ \\
\hline Headache duration (h) & $4.033 \pm 7.325$ & $3.414 \pm 6.859$ & $\mathbf{0 . 0 0 0}$ \\
\hline Headache days per month & $2.092 \pm 3.694$ & $1.788 \pm 2.989$ & $\mathbf{0 . 0 0 0}$ \\
\hline
\end{tabular}

Figure 3 presents self-reported factors associated with remission or deterioration in headache during COVID-19. Participants reported decreased stress (19.35\%), changes in the law of life (14.18\%), good sleep quality $(15.00 \%)$ or others $(5.35 \%)$ as factors associated with headache remission, while increased stress $(27.48 \%)$, bad sleep quality $(29.12 \%)$, decreased social interaction $(10.23 \%)$, changes in the law of life $(4.45 \%)$ or others $(1.00 \%)$ as factors associated with headache aggravation.

Application of the International Headache Society (IHS) criteria ${ }^{15}$ generated the following diagnosis of headache: 378 respondents had migraine, 1385 had tension-type headache (TTH), and 100 had cluster headache $(\mathrm{CH})$. We observed that, remission in headache duration during COVID-19 differentiated significantly among different headache types (Fig. 4). Post hoc analysis using Bonferroni test showed that migraine presented higher remission rate of headache duration, compared with TTH $(30.95 \% \mathrm{vs}$ $25.05 \%, \mathrm{P}=0.021)$ and $\mathrm{CH}(30.95 \%$ vs $8.00 \%, \mathrm{P}=0.000)$. Besides, $\mathrm{TTH}$ presented higher remission rate of headache duration, compared with $\mathrm{CH}(25.05 \%$ vs $8.00 \%, \mathrm{P}=0.000)$. 
Comparison of demographic characteristics for the remission group, unchanged group and aggravating group.

Table 2 presents comparison of demographic characteristics for the remission group, unchanged group and aggravating group according to headache duration. 
Table 2

Comparison of demographic characteristics for the remission group, unchanged group and aggravating group according to headache duration

\begin{tabular}{|c|c|c|c|c|c|c|c|}
\hline \multirow[t]{2}{*}{ characteristics } & \multirow{2}{*}{$\begin{array}{l}\text { The } \\
\text { remission } \\
\text { group }{ }^{1}(n= \\
686)\end{array}$} & \multirow{2}{*}{$\begin{array}{l}\text { The } \\
\text { unchanged } \\
\text { group }{ }^{2}(n= \\
1936)\end{array}$} & \multirow{2}{*}{$\begin{array}{l}\text { The } \\
\text { aggravating } \\
\text { group }{ }^{3}(\mathrm{n}= \\
\text { 184) }\end{array}$} & \multirow{2}{*}{$\begin{array}{l}\mathrm{P} \\
\text { value }\end{array}$} & \multicolumn{3}{|c|}{ P value Post hoc } \\
\hline & & & & & $2^{1 \text { vs }}$ & $\begin{array}{l}1 \text { vs } \\
3\end{array}$ & 2 vs \\
\hline Male, n (\%) & 251(36.59) & 715(36.93) & $77(44.85)$ & 0.393 & & & \\
\hline Age, n (\%) & & & & 0.253 & & & \\
\hline$<30$ & $176(25.66)$ & $441(22.78)$ & $53(28.80)$ & & & & \\
\hline $30-50$ & $463(67.49)$ & 1371(70.82) & $120(65.22)$ & & & & \\
\hline$>50$ & $47(6.85)$ & $124(6.40)$ & $11(5.98)$ & & & & \\
\hline $\begin{array}{l}\text { Education level, } \\
\text { n (\%) }\end{array}$ & & & & 0.035 & 0.152 & 0.172 & 0.018 \\
\hline $\begin{array}{l}\text { junior colleague } \\
\text { or lower }\end{array}$ & $150(21.87)$ & $374(19.32)$ & $49(26.63)$ & & & & \\
\hline $\begin{array}{l}\text { University or } \\
\text { above }\end{array}$ & $536(78.13)$ & 1562(80.68) & 135(73.37) & & & & \\
\hline $\begin{array}{l}\text { Chronic disease } \\
\text { history, n (\%) }\end{array}$ & 167(24.34) & $444(22.93)$ & $52(28.26)$ & 0.253 & & & \\
\hline Smoking, n (\%) & $91(13.27)$ & $334(17.25)$ & $47(25.54)$ & 0.000 & 0.015 & 0.000 & 0.005 \\
\hline Drinking, n (\%) & 279(40.67) & $813(41.99)$ & $88(47.83)$ & 0.217 & & & \\
\hline $\begin{array}{l}\text { Living in } \\
\text { Wuhan, } \mathrm{n}(\%)\end{array}$ & $20(2.92)$ & $63(3.25)$ & 13(7.07) & 0.018 & 0.663 & 0.009 & 0.008 \\
\hline $\begin{array}{l}\text { Having COVID- } \\
19 \text { symptoms or }\end{array}$ & $45(6.56)$ & $86(4.44)$ & $20(10.87)$ & 0.000 & 0.029 & 0.048 & 0.000 \\
\hline $\begin{array}{l}\text { CoVID-19 } \\
\text { diagnosis, n (\%) }\end{array}$ & & & & & & & \\
\hline $\begin{array}{l}\text { Having relative } \\
\text { or acquaintance } \\
\text { got }\end{array}$ & $80(11.66)$ & $240(12.40)$ & $38(20.65)$ & 0.004 & 0.613 & 0.002 & 0.002 \\
\hline COVID-19, n (\%) & & & & & & & \\
\hline $\begin{array}{l}\text { Getting support } \\
\text { from family } \\
\text { members, n (\%) }\end{array}$ & & & & 0.001 & 0.015 & 0.000 & 0.005 \\
\hline $\begin{array}{l}\text { Unchanged or } \\
\text { more }\end{array}$ & $659(96.06)$ & $1811(93.54)$ & 163 (88.59) & & & & \\
\hline Less & $27(3.94)$ & $125(6.46)$ & $21(11.41)$ & & & & \\
\hline
\end{tabular}




\begin{tabular}{|c|c|c|c|c|c|c|c|}
\hline \multirow[t]{2}{*}{ characteristics } & \multirow{2}{*}{$\begin{array}{l}\text { The } \\
\text { remission } \\
\text { group }{ }^{1}(\mathrm{n}= \\
686)\end{array}$} & \multirow{2}{*}{$\begin{array}{l}\text { The } \\
\text { unchanged } \\
\text { group } 2(n= \\
1936)\end{array}$} & \multirow{2}{*}{$\begin{array}{l}\text { The } \\
\text { aggravating } \\
\text { group }{ }^{3}(n= \\
\text { 184) }\end{array}$} & \multirow{2}{*}{$\begin{array}{l}P \\
\text { value }\end{array}$} & \multicolumn{3}{|c|}{ P value Post hoc } \\
\hline & & & & & $2^{1 \text { vs }}$ & $\begin{array}{l}1 \text { vs } \\
3\end{array}$ & $\begin{array}{l}2 \text { vs } \\
3\end{array}$ \\
\hline $\begin{array}{l}\text { Getting support } \\
\text { from the outside } \\
\text { world, } n(\%)\end{array}$ & & & & 0.028 & 0.056 & 0.011 & 0.120 \\
\hline $\begin{array}{l}\text { Unchanged or } \\
\text { more }\end{array}$ & 599 (87.32) & $1632(84.30)$ & 147 (79.89) & & & & \\
\hline Less & $87(12.68)$ & $304(15.70)$ & $37(20.11)$ & & & & \\
\hline ISI score & $6.70 \pm 5.30$ & $8.16 \pm 5.67$ & $10.22 \pm 6.01$ & 0.000 & 0.000 & 0.000 & 0.000 \\
\hline PHQ9 score & $5.99 \pm 4.74$ & $6.92 \pm 4.93$ & $8.74 \pm 4.89$ & 0.000 & 0.000 & 0.000 & 0.000 \\
\hline ISER score & $\begin{array}{l}17.99 \pm \\
14.18\end{array}$ & $21.08 \pm 14.63$ & $\begin{array}{l}27.71 \pm \\
16.96\end{array}$ & 0.000 & 0.000 & 0.000 & 0.000 \\
\hline
\end{tabular}

686 of 2806 participants (24.45\%) tended to improve in headache duration during COVID-19, 1936 (68.99\%) remain unchanged, and 184 (6.56\%) worsen. An initial comparative analysis showed significant difference in education level $(P=0.035)$, smoking $(P=0.000)$, place of residence $(P=0.018)$, COVID-19 symptoms or COVID-19 diagnosis $(P=0.000)$, relative or acquaintance got COVID-19 $(P=0.004)$, getting support from family members $(P=0.001)$, getting support from the outside world $(P=0.028)$ during the social isolation, ISI $(P=0.000)$, PHQ-9 $(P=0.000)$ and ISE-R $(P=0.000)$. Post hoc comparisons using Bonferroni test evidenced that the aggravating group presented significantly higher proportion of smoking, living in Wuhan area, having relative or acquaintance got COVID-19, getting less support from family members during the social isolation, and significantly higher ISI, PHQ-9 and ISE-R score, compared with the remission group $(P=0.000, P=0.009, P=0.002, P=0.000, P=0.000, P=0.000, P=0.000)$ and unchanged group $(P=0.005, P=0.008, P=0.002, P=0.005, P=0.000, P=0.000, P=0.000)$. The aggravating group also demonstrated significantly higher proportion of having COVID-19 symptoms or COVID-19 diagnosis, compared with the unchanged group $(P=0.000)$, and higher proportion of getting less support from the outside world during the social isolation, compared with the remission group $(\mathrm{P}=$ $0.011)$.

Table 3 presents comparison of demographic characteristics for the remission group, unchanged group and aggravating group according to headache frequency (days per month). 
Table 3

Comparison of demographic characteristics for the remission group, unchanged group and aggravating group according to headache frequency.

\begin{tabular}{|c|c|c|c|c|c|c|c|}
\hline \multirow[t]{2}{*}{ characteristics } & \multirow{2}{*}{$\begin{array}{l}\text { The } \\
\text { remission } \\
\text { group }{ }^{1}(n= \\
737)\end{array}$} & \multirow{2}{*}{$\begin{array}{l}\text { The } \\
\text { unchanged } \\
\text { group }{ }^{2}(n= \\
1790)\end{array}$} & \multirow{2}{*}{$\begin{array}{l}\text { The } \\
\text { aggravating } \\
\text { group }{ }^{3}(\mathrm{n}= \\
279)\end{array}$} & \multirow{2}{*}{$\begin{array}{l}\mathrm{P} \\
\text { value }\end{array}$} & \multicolumn{3}{|c|}{ P value Post hoc } \\
\hline & & & & & $2^{1 \text { vs }}$ & $\begin{array}{l}1 \text { vs } \\
3\end{array}$ & 2 vs \\
\hline Male, n (\%) & 289(39.21) & 633(35.36) & $21(43.47)$ & 0.015 & 0.068 & 0.228 & 0.010 \\
\hline Age, n (\%) & & & & 0.431 & & & \\
\hline$<30$ & 185(25.10) & $410(22.91)$ & $75(26.88)$ & & & & \\
\hline $30-50$ & $502(68.11)$ & $1263(70.56)$ & $190(68.10)$ & & & & \\
\hline$>50$ & $50(6.79)$ & 117(6.53) & 14(7.82) & & & & \\
\hline $\begin{array}{l}\text { Education level, } \\
\text { n (\%) }\end{array}$ & & & & 0.260 & & & \\
\hline $\begin{array}{l}\text { junior colleague } \\
\text { or lower }\end{array}$ & 152(20.62) & $354(19.78)$ & $64(24.01)$ & & & & \\
\hline $\begin{array}{l}\text { University or } \\
\text { above }\end{array}$ & 585(79.38) & 1456(80.22) & 212(75.99) & & & & \\
\hline $\begin{array}{l}\text { Chronic disease } \\
\text { history, n (\%) }\end{array}$ & 184(24.97) & $385(21.51)$ & 94(33.69) & 0.000 & 0.059 & 0.005 & 0.000 \\
\hline Smoking, n (\%) & $123(16.69)$ & 291(16.26) & $58(20.79)$ & 0.169 & & & \\
\hline Drinking, n (\%) & $316(42.88)$ & $725(40.50)$ & 139(49.82) & 0.012 & 0.270 & 0.047 & 0.003 \\
\hline $\begin{array}{l}\text { Living in } \\
\text { Wuhan, } \mathrm{n}(\%)\end{array}$ & $18(2.44)$ & $59(3.30)$ & $19(6.81)$ & 0.003 & 0.256 & 0.001 & 0.004 \\
\hline $\begin{array}{l}\text { Having COVID- } \\
19 \text { symptoms or }\end{array}$ & $41(5.56)$ & $75(4.19)$ & $35(12.54)$ & 0.000 & 0.134 & 0.000 & 0.000 \\
\hline $\begin{array}{l}\text { COVID-19 } \\
\text { diagnosis, n (\%) }\end{array}$ & & & & & & & \\
\hline $\begin{array}{l}\text { Having relative } \\
\text { or acquaintance } \\
\text { got }\end{array}$ & $90(12.31)$ & $202(11.28)$ & $66(23.66)$ & 0.000 & 0.508 & 0.000 & 0.000 \\
\hline COVID-19, n (\%) & & & & & & & \\
\hline $\begin{array}{l}\text { Getting support } \\
\text { from family } \\
\text { members, n (\%) }\end{array}$ & & & & 0.027 & 0.407 & 0.071 & 0.007 \\
\hline $\begin{array}{l}\text { Unchanged or } \\
\text { more }\end{array}$ & $690(93.62)$ & 1691 (94.47) & 252 (90.32) & & & & \\
\hline Less & $47(6.38)$ & $99(5.53)$ & $27(9.68)$ & & & & \\
\hline
\end{tabular}




\begin{tabular}{|c|c|c|c|c|c|c|c|}
\hline \multirow[t]{2}{*}{ characteristics } & \multirow{2}{*}{$\begin{array}{l}\text { The } \\
\text { remission } \\
\text { group }{ }^{1}(\mathrm{n}= \\
737)\end{array}$} & \multirow{2}{*}{$\begin{array}{l}\text { The } \\
\text { unchanged } \\
\text { group } 2(n= \\
1790)\end{array}$} & \multirow{2}{*}{$\begin{array}{l}\text { The } \\
\text { aggravating } \\
\text { group }{ }^{3}(n= \\
279)\end{array}$} & \multirow{2}{*}{$\begin{array}{l}P \\
\text { value }\end{array}$} & \multicolumn{3}{|c|}{ P value Post hoc } \\
\hline & & & & & $2^{1 \mathrm{vs}}$ & $3^{1 \text { vs }}$ & $\begin{array}{l}2 \text { vs } \\
3\end{array}$ \\
\hline $\begin{array}{l}\text { Getting support } \\
\text { from the outside } \\
\text { world, } n(\%)\end{array}$ & & & & 0.258 & & & \\
\hline $\begin{array}{l}\text { Unchanged or } \\
\text { more }\end{array}$ & $635(86.16)$ & $1514(84.58)$ & 229 (82.08) & & & & \\
\hline Less & 102(13.84) & $276(15.42)$ & $50(17.92)$ & & & & \\
\hline ISI score & $6.99 \pm 5.48$ & $8.25 \pm 5.66$ & $8.42 \pm 5.93$ & 0.000 & 0.000 & 0.000 & 1.000 \\
\hline PHQ9 score & $6.18 \pm 4.84$ & $7.00 \pm 4.88$ & $7.28 \pm 5.27$ & 0.000 & 0.000 & 0.006 & 1.000 \\
\hline ISER score & $\begin{array}{l}18.79 \pm \\
14.83\end{array}$ & $21.32 \pm 14.57$ & $\begin{array}{l}22.36 \pm \\
16.25\end{array}$ & 0.000 & 0.000 & 0.002 & 1.000 \\
\hline
\end{tabular}

737 of 2806 participants (26.27\%) tended to improve in headache frequency (days per month). during COVID-19, 1790 (63.79\%) remain unchanged, and 279 (9.94\%) worsen. An initial comparative analysis showed significant difference in gender $(P=0.015)$, chronic disease history $(P=0.000)$, drinking $(P=$ 0.012), place of residence $(P=0.003)$, COVID-19 symptoms or COVID-19 diagnosis $(P=0.000)$, relative or acquaintance got COVID-19 $(P=0.000)$, getting support from family members during the social isolation $(P=0.027), I S I(P=0.000), P H Q-9(P=0.000)$ and ISE-R $(P=0.000)$. Post hoc comparisons using Bonferroni test evidenced that the aggravating group presented significantly higher proportion of having underlying diseases, living in Wuhan area, having COVID-19 symptoms or COVID-19 diagnosis, and having relative or acquaintance got COVID-19, compared with the remission group $(P=0.005, P=0.001, P$ $=0.000, P=0.000, P=0.000)$ and unchanged group $(P=0.000, P=0.004, P=0.000, P=0.000)$. The aggravating group also demonstrated significantly higher proportion of males $(P=0.010)$, drinking $(P=$ $0.003)$ and getting less support from family members during the social isolation $(P=0.007)$, compared with the unchanged group, and higher ISI $(P=0.000)$, PHQ-9 $(P=0.006)$ and ISE-R score $(P=0.002)$, compared with the remission group.

Table 4 presents comparison of demographic characteristics for the remission group, unchanged group and aggravating group according to headache intensity. 
Table 4

Comparison of demographic characteristics for the remission group, unchanged group and aggravating group according to headache intensity.

\begin{tabular}{|c|c|c|c|c|c|c|c|}
\hline \multirow[t]{2}{*}{ characteristics } & \multirow{2}{*}{$\begin{array}{l}\text { The } \\
\text { remission } \\
\text { group }{ }^{1}(n= \\
258)\end{array}$} & \multirow{2}{*}{$\begin{array}{l}\text { The } \\
\text { unchanged } \\
\text { group }{ }^{2}(n= \\
2451)\end{array}$} & \multirow{2}{*}{$\begin{array}{l}\text { The } \\
\text { aggravating } \\
\text { group }{ }^{3}(\mathrm{n}= \\
97)\end{array}$} & \multirow{2}{*}{$\begin{array}{l}\mathrm{P} \\
\text { value }\end{array}$} & \multicolumn{3}{|c|}{ P value Post hoc } \\
\hline & & & & & $2^{1 \text { vs }}$ & $\begin{array}{l}1 \text { vs } \\
3\end{array}$ & 2 vs \\
\hline Male, n (\%) & 101(39.15) & $901(36.76)$ & $41(42.27)$ & 0.430 & & & \\
\hline Age, n (\%) & & & & 0.047 & & & \\
\hline$<30$ & $77(29.84)$ & $563(22.97)$ & $30(30.93)$ & & & & \\
\hline $30-50$ & 163(63.18) & 1731(70.62) & $60(61.86)$ & & & & \\
\hline$>50$ & 18(6.98) & $157(6.41)$ & $7(7.21)$ & & & & \\
\hline $\begin{array}{l}\text { Education level, } \\
\text { n (\%) }\end{array}$ & & & & 0.019 & 0.005 & 0.209 & 0.825 \\
\hline $\begin{array}{l}\text { junior colleague } \\
\text { or lower }\end{array}$ & $70(27.13)$ & 483(19.71) & $20(20.62)$ & & & & \\
\hline $\begin{array}{l}\text { University or } \\
\text { above }\end{array}$ & 188(72.87) & 1968(80.29) & 77(79.38) & & & & \\
\hline $\begin{array}{l}\text { Chronic disease } \\
\text { history, n (\%) }\end{array}$ & $68(26.36)$ & $567(23.13)$ & 28(28.87) & 0.238 & & & \\
\hline Smoking, n (\%) & $53(20.54)$ & $398(16.24)$ & $21(21.65)$ & 0.000 & 0.000 & 0.000 & 0.083 \\
\hline Drinking, n (\%) & $121(46.90)$ & $1010(41.21)$ & $49(50.52)$ & 0.048 & 0.078 & 0.543 & 0.068 \\
\hline $\begin{array}{l}\text { Living in } \\
\text { Wuhan, } \mathrm{n}(\%)\end{array}$ & $11(4.26)$ & 77(3.14) & $8(8.25)$ & 0.019 & 0.334 & 0.137 & 0.006 \\
\hline $\begin{array}{l}\text { Having COVID- } \\
19 \text { symptoms or }\end{array}$ & $20(7.75)$ & $121(4.94)$ & $10(10.31)$ & 0.015 & 0.053 & 0.440 & 0.030 \\
\hline $\begin{array}{l}\text { CoVID-19 } \\
\text { diagnosis, n (\%) }\end{array}$ & & & & & & & \\
\hline $\begin{array}{l}\text { Having relative } \\
\text { or acquaintance } \\
\text { got }\end{array}$ & $47(18.22)$ & $276(11.26)$ & $35(36.08)$ & 0.000 & 0.001 & 0.000 & 0.000 \\
\hline COVID-19, n (\%) & & & & & & & \\
\hline $\begin{array}{l}\text { Getting support } \\
\text { from family } \\
\text { members, n (\%) }\end{array}$ & & & & 0.002 & 0.060 & 0.170 & 0.001 \\
\hline $\begin{array}{l}\text { Unchanged or } \\
\text { more }\end{array}$ & 236 (91.47) & 2313 (94.37) & $84(86.60)$ & & & & \\
\hline Less & $22(8.53)$ & $138(5.63)$ & $13(13.40)$ & & & & \\
\hline
\end{tabular}




\begin{tabular}{|c|c|c|c|c|c|c|c|}
\hline \multirow[t]{2}{*}{ characteristics } & \multirow{2}{*}{$\begin{array}{l}\text { The } \\
\text { remission } \\
\text { group }{ }^{1}(\mathrm{n}= \\
258)\end{array}$} & \multirow{2}{*}{$\begin{array}{l}\text { The } \\
\text { unchanged } \\
\text { group } 2(n= \\
2451)\end{array}$} & \multirow{2}{*}{$\begin{array}{l}\text { The } \\
\text { aggravating } \\
\text { group }{ }^{3}(n= \\
97)\end{array}$} & \multirow{2}{*}{$\begin{array}{l}P \\
\text { value }\end{array}$} & \multicolumn{3}{|c|}{ P value Post hoc } \\
\hline & & & & & $2^{1 \text { vs }}$ & $3^{1} \mathrm{vs}$ & $\frac{2}{3}$ vs \\
\hline $\begin{array}{l}\text { Getting support } \\
\text { from the outside } \\
\text { world, } n(\%)\end{array}$ & & & & 0.112 & & & \\
\hline $\begin{array}{l}\text { Unchanged or } \\
\text { more }\end{array}$ & $221(85.66)$ & $2082(84.94)$ & 75 (77.32) & & & & \\
\hline Less & $37(14.34)$ & $369(15.06)$ & $22(22.68)$ & & & & \\
\hline ISI score & $7.52 \pm 5.57$ & $8.04 \pm 5.68$ & $6.50 \pm 5.44$ & 0.009 & 0.494 & 0.225 & 0.014 \\
\hline PHQ9 score & $6.83 \pm 5.34$ & $6.85 \pm 4.90$ & $5.80 \pm 4.38$ & 0.110 & & & \\
\hline ISER score & $\begin{array}{l}20.82 \pm \\
15.42\end{array}$ & $20.86 \pm 14.85$ & $\begin{array}{l}18.03 \pm \\
13.39\end{array}$ & 0.294 & & & \\
\hline
\end{tabular}

258 of 2806 participants (9.19\%) tended to improve in headache days during COVID-19, 2451 (87.35\%) remain unchanged, and 97 (3.46\%) worsen. An initial comparative analysis showed significant difference in age $(P=0.047)$, education level $(P=0.019)$, smoking $(P=0.000)$, drinking $(P=0.048)$, place of residence $(P=0.019)$, COVID-19 symptoms or COVID-19 diagnosis $(P=0.015)$, relative or acquaintance got COVID$19(P=0.000)$, getting support from family members during the social isolation $(P=0.002)$ and ISI $(P=$ 0.009). Post hoc comparisons using Bonferroni test evidenced that the aggravating group presented significantly higher proportion of having relative or acquaintance got COVID-19, compared with the remission group $(P=0.000)$ and unchanged group $(P=0.000)$. The aggravating group also demonstrated significantly higher proportion of smoking $(P=0.000)$, compared with the remission group, and significantly higher proportion of living in Wuhan area $(P=0.006)$ and getting less support from family members during the social isolation $(P=0.001)$, and lower ISI score $(P=0.014)$, compared with the unchanged group.

Figure 5 shows that participants living in Wuhan area, having COVID-19 symptoms or COVID-19 diagnosis and having relative or acquaintance got COVID-19 are more likely to get headache deteriorated. Participants living in Wuhan area took a higher exacerbation rate of headache duration $(13.54 \%$ vs $6.31 \%$, $P=0.005)$, headache days $(19.79 \%$ vs $9.59 \%, P=0.001)$ and headache intensity $(8.33 \%$ vs $3.28 \%, P=$ 0.008). And participants having COVID-19 symptoms or COVID-19 diagnosis took a higher exacerbation rate of headache duration ( $13.25 \%$ vs $6.18 \%, P=0.001)$, headache days $(23.18 \%$ vs $9.19 \%, P=0.000)$ and headache intensity $(6.62 \%$ vs $3.28 \%, P=0.029)$. Participants having relative or acquaintance got COVID19 also took a higher exacerbation rate of headache duration $(10.61 \%$ vs $5.96 \%, P=0.001)$, headache days $(18.44 \%$ vs $8.70 \%, P=0.000)$ and headache intensity $(9.78 \%$ vs $2.53 \%, P=0.000)$.

\section{Predictors of remission}


Table 5, 6, 7 shows details of multivariate logistic regression analyses of factor associated with remission in headache duration, headache days and headache intensity respectively. Smoking (OR = $1.397,95 \% \mathrm{Cl} 1.090$ to $1.790, \mathrm{P}=0.008$ ) and getting support from family members during the social isolation ( $\mathrm{OR}=1.656,95 \% \mathrm{Cl} 1.075$ to $2.550, \mathrm{P}=0.022)$ were the independent factors of remission in headache duration. Participants without a history of smoking or getting unchanged or more support from family members during the social isolation were more likely to have remission in headache duration. ISE$R$ score had no clinical significance for remission in headache duration $(O R=1.009,95 \% \mathrm{Cl} 1.002$ to 1.016), though a p-value $<0.05$ was got. Similarly, ISI score ( $O R=0.968,95 \% \mathrm{Cl} 0.948$ to 0.989$)$ had no clinical significance for remission in headache days, though a p-value $<0.05$ was got. Education level (OR $=1.478,95 \% \mathrm{Cl} 1.103$ to $1.980, \mathrm{P}=0.009)$ and having relative or acquaintance got COVID-19 $(\mathrm{OR}=0.643$, $95 \% \mathrm{Cl} 0.458$ to $0.902, \mathrm{P}=0.011$ ) were the independent factors of remission in headache severity.

Participants of low education or having relative or acquaintance got COVID-19 were more likely to have remission in headache.

Table 5

Predictors of remission in headache duration.

\begin{tabular}{|llc|}
\hline Variables & OR $(95 \%$ Cl) & P value \\
\hline Smoking $^{1}$ & $1.397(1.090-1.790)$ & 0.008 \\
\hline Getting support from family members ${ }^{2}$ & $1.656(1.075-2.550)$ & 0.022 \\
\hline Getting support from the outside world ${ }^{3}$ & $1.218(0.938-1.580)$ & 0.139 \\
\hline ISI score & $1.013(0.992-1.034)$ & 0.232 \\
\hline PHQ9 score & $1.006(0.982-1.031)$ & 0.619 \\
\hline ISER score & $1.009(1.002-1.016)$ & 0.016 \\
\hline 1, non-smoking vs smoking; & & \\
\hline $\begin{array}{l}\text { 2, Getting Unchanged or more support from family members vs Getting less support from family } \\
\text { members; }\end{array}$ & & \\
\hline $\begin{array}{l}\text { 3, Getting Unchanged or more support from the outside world vs Getting less support from family } \\
\text { members. }\end{array}$ & \\
\hline
\end{tabular}

Table 6

Predictors of remission in headache frequency

\begin{tabular}{|lll|}
\hline Variables & OR $(95 \% \mathrm{Cl})$ & P value \\
\hline ISI score & $0.968(0.948-0.989)$ & $\mathbf{0 . 0 0 3}$ \\
\hline PHQ9 score & $0.997(0.973-1.022)$ & 0.809 \\
\hline ISER score & $0.994(0.987-1.002)$ & 0.131 \\
\hline
\end{tabular}


Table 7

Predictors of remission in headache intensity

\begin{tabular}{|llc|}
\hline Variables & OR $(95 \% \mathrm{Cl})$ & P value \\
\hline Having relative or acquaintance & $0.643(0.458-0.902)$ & 0.011 \\
got COVID-19 1 & & 0.009 \\
\hline Education level $^{3}$ & $1.478(1.103-1.980)$ & \\
\hline 1, Not having relative or acquaintance got COVID-19 vs having relative or acquaintance got COVID-19; & \\
\hline 2, junior colleague or lower vs University or above. &
\end{tabular}

\section{Discussion}

To our knowledge, the present study was the first research to investigate the impact of COVID-19 pandemic on headache patients in China. Our analysis showed a reality of those headache participants with remission of headache duration, headache days per month, and headache intensity during COVID19. Smoking, education level and getting support from family members during the social isolation were the independent factors of remission in headache during COVID-19. Besides, participants living in Wuhan area, having COVID-19 symptoms or COVID-19 diagnosis and having relative or acquaintance got COVID19 are more likely to get headache deteriorated.

A previous door-to-door population-based survey reported the headache epidemiological data among China. Of 5041 respondents, 1425 reported headache in the preceding year, giving a 1-year prevalence of $28.5 \%$. Headache was more prevalent in females $(36.8 \%)$, than in males $(23.8 \%)^{16}$. Similar to the previous study, our analysis showed a higher prevalence of headache in females $(20.57 \%)$, compared with that in males $(16.22 \%)$, while the headache prevalence in the present study was $18.71 \%$, slightly lower than in the previous study. Besides, prevalence of headache peaked during adolescence. As shown in previous studies, headache prevalence among childhood or adolescence varied widely, from 5.9 to $82 \%$, bringing high costs to individual and society ${ }^{17-19}$. It presented a gradual upward trend throughout childhood, peaking at about 11 to 13 years old ${ }^{17-18}$. And headache in children or adolescents can result in impaired psychosocial function, as a major factor associated with school absenteeism and poorer quality of life ${ }^{18}$. A consensus was reached that the natural pattern of headache may change through childhood to adulthood ${ }^{18}$. Hormonal changes, different levels of stress exposure, and the life events and circumstances behind each stress exposure were the possible explanations for the evolution of headaches over time ${ }^{18}$. Moreover, those who had headaches in childhood or adolescence may be at a higher risk of getting additional physical or psychological problems in adulthood ${ }^{19}$. Given that headache in childhood or adolescents had a high prevalence, and caused various negative effects not only on childhood but also on adulthood, it is vital for us to understand the clinical feature and evolution of headache from childhood to adulthood. 
The main target of this research was to investigate the impact of COVID-19 pandemic on headache patients in China. Interestingly, but not surprisingly, our analysis showed a reality of those headache participants with a tendency to improve or remit in headache duration, headache frequency and headache intensity during COVID-19 outbreak. Meanwhile, we inquire some headache patients, as well as friends and colleagues. In line with the present study, they reported a tendency to improve or remit in headache attacks during the social isolation. We also observed that, migraine was more likely to have remission in headache duration, compared with $\mathrm{TTH}$ and $\mathrm{CH}$. Further work is required to demonstrated the underlying causes.

Previous studies demonstrated evidences that the risk of headache attacks decreased in holidays or days off ${ }^{20}$. Due to the war against COVID-19, we got a special long holiday. Then, why does the holiday give participants a remission in headache attacks? Several factors are particularly noteworthy to report. For instance, time off is important for workers or students to recover from load effects accumulated at work or study ${ }^{21}$. Less stress from work or study could be a factor related to headache remission during the social isolation. Additionally, previous studies reported not eating on time as a precipitating factor of headache attacks ${ }^{22-23}$. The underlying mechanism could be explained by causing relative hypoglycemia, further activating the adrenal medulla ${ }^{21}$. Eat regularly during the special holiday could be another factor related to headache remission. Then, sleep quality is an acknowledged factor affecting headache attacks. Our analysis showed that ISI scores were significantly lower in the remission group than in the aggravating group. Also, it should be particularly emphasized that getting support from family members during the social isolation were the independent factors of remission in headache duration. A previous study demonstrated that patients from functional families appeared to show relatively low levels of distress regardless of the severity of their headache ${ }^{24}$. COVID-19 outbroke when Spring Festival was approaching, the period for a reunion with family members in China. Families got together during the special holiday, and have more time to communicate and listen to each other. Similarly, with regard to headache participants, they got more opportunities to communicate their headache-related problems with family members and obtained more effective support, thus reduced the headache-related or mental burden. Given that, we call on more family supports involved to help headache patients improve or remit in headache attacks.

Besides getting support from family members, education level and smoking were also independent factors of remission in headache attacks. A previous study showed that remission was positively associated with increased educational level ${ }^{25}$. On the contrary, another study demonstrated that participants with higher education tended to having more headaches, especially migraine ${ }^{26}$. The present study found that participants with a junior colleague or lower degree were more likely to have remission in headache severity during COVID-19, compared with participants with a university degree. Smoking was a precipitating factor of headache attacks. Participants not smoking were more likely to have remission in headache duration. Rather curiously multivariate logistic regression analyses showed that having relative or acquaintance got COVID-19 was a protective factor factors of remission in headache severity. By synthesizing the data, we found that the aggravating group presented significantly higher proportion of 
participants having relative or acquaintance got COVID-19, compared with the remission group and unchanged group, while the unchanged group presented a significantly lower proportion, compared with the remission group. And participants in the unchanged group greatly outnumber participants in the aggravating group (Table 4), which significantly offset the adverse effect of having relative or acquaintance got COVID-19 on headache severity.

Though participants presented an overall trend of headache remission, adverse impacts of COVID-19related events on headache cannot be overlooked. Participants living in Wuhan area, having COVID-19 symptoms or COVID-19 diagnosis and having relative or acquaintance got COVID-19 are more likely to get headache deteriorated. COVID-19 outbreak is a stress event, causing varying degrees of anxiety and worry, and some even developed post-traumatic stress disorder. With regard to headache participants, they were more vulnerable when faced stress events. So it is understandable that COVID-19-related events were precipitating factors of headache attacks. Most of participants included in the present study lived outside Wuhan, having no COVID-19 symptoms or COVID-19 diagnosis and having no relative or acquaintance got COVID-19. For most people, they were less affected by the COVID-19 outbreak, and thus tended to have headache unchanged or remission.

A previous study ${ }^{27}$ reported that the seropositive prevalence rate of antibodies (IgM or IgG) against SARSCoV-2 was $0.8 \%$ in the general Chinese population. In the present study, the overall prevalence of SARSCoV-2 infection was $0.15 \%$, which roughly matched the general prevalence of COVID-19 in the Chinese population. Given that the sample size is large enough, results reported in the present study are more likely generalizable. However, we acknowledge some limitations of our study. First, since the study was based on a self-administered questionnaire, it could be inevitably affected by the recall bias. Besides, it is difficult for us to identify what types of headache the respondents had. Further work is needed. Second, the number of participants infected with COVID-19 included in our study was very few. We could not exactly report the impact of COVID-19 infection on headache attacks. The prevalence of SARS-CoV-2 infection in headache participants was $0.2 \%(6 / 2806)$. No significant difference was found when compared with the prevalence of SARS-CoV-2 infection in non-headache participants (16/12194, 0.13\%). Additionally, headache participants confirmed with SARS-CoV-2 infection showed a higher exacerbation rate of headache intensity, when compared with headache participants not confirmed with SARS-CoV-2 infection $(50.00 \%$ vs $3.36 \%, P=0.001)$. Further study would be needed to identify the impact of COVID-19 infection on headache attacks. Third, sampling error is unavoidable by using this online questionnaire, for example, illiterate, the elderly, children and those who cannot afford to buy a smartphone may have a less participation in the survey. Fourth, some factors such as BMI, marriage status and regular diet were not assessed.

\section{Conclusion}

The present study provided the first data about the impact of COVID-19 pandemic on headache patients in China. Adverse impacts of COVID-19-related events on headache patients, especially those living in high-risk area, cannot be overlooked, though participants presented an overall trend of headache 
remission during COVID-19. Smoking, education level and getting support from family members during the social isolation were the independent factors of remission in headache. We call on more family supports involved to help headache patients improve or remit in headache attacks.

\section{Abbreviations}

COVID-19: coronavirus disease 2019; PPE: personal protective equipment; RAS: renin-angiotensin system; NSAID: non-steroid anti-inflammatory drug; PHQ-9: Patient Health Questionnaire-9; ISI: Insomnia Severity Index; IES-R: Impact of Event Scale Revised; HIS: International Headache Society; TTH: tension-type headache; $\mathrm{CH}$ : cluster headache.

\section{Declarations}

\section{Ethics approval and consent to participate}

This retrospective study was approved by the ethics committee of the Remin hospital of Wuhan University, Wuhan, china. The informed consent was waived.

\section{Consent for publication}

Not applicable.

\section{Availability of data and materials}

Data used for analysis are available from the corresponding author on reasonable request.

\section{Competing interests}

The authors declare that they have no competing interests.

\section{Funding}

This work was supported by grants from the National Natural Science Foundation of China (81471133, 30900459, 81971055), the Natural Science Foundation of Hubei Province, China (2014CFB734) and the National Key R\&D Program of China (2018YFC1314600). The sponsors played no role in the study design, data collection, and analysis, or decision to submit the article for publication.

\section{Authors' contributions}

QG contributed to the study design. QG, SL, RL, LY and ZX contributed to data acquisition and analysis. QG wrote the manuscript. ZX reviewed the manuscript. All authors read and approved the final manuscript.

\section{Acknowledgements}


Not applicable.

\section{References}

[1] Richard M, Kok A, de Meulder D, et al. SARS-CoV-2 is transmitted via contact and via the air between ferrets[J]. Nat Commun, 2020, 11(1): 3496. doi: 10.1038/s41467-020-17367-2

[2] Huang C, Wang Y, Li X, et al. Clinical features of patients infected with 2019 novel

coronavirus in Wuhan, China[J]. Lancet, 2020, 395(10223): 497-506. doi: 10.1016/S0140-6736(20)301835 .

[3] Mao, L, Jin, H, Wang, M, et al. Neurologic manifestations of hospitalized patients with coronavirus disease 2019 in Wuhan, China[J]. JAMA neurology, 2020, 77(6): 1-9. doi: 10.1001/jamaneurol.2020.1127.

[4] Bolay H, Gül A, Baykan B. COVID-19 is a Real Headache! [J]. Headache, 2020, doi:

10.1111/head.13856.

[5] Ong JJY, Bharatendu C, Goh Y, et al. Headaches Associated With Personal Protective Equipment - A Cross-Sectional Study Among Frontline Healthcare Workers During COVID-19[J]. Headache, 2020, 60(5): 864-877. doi: 10.1111/head.13811.

[6] Szperka CL, Ailani J, Barmherzig R, et al. Migraine Care in the Era of COVID-19: Clinical Pearls and Plea to Insurers[J]. Headache, 2020, 60(5): 833-842. doi: 10.1111/head.13810.

[7] Porta-Etessam J, Gonzalez-Garcia N, Matias-Guiu JA, et al. Should we adapt the prescription criteria for specific treatments for migraine due to the Covid-19 pandemic?[J]. Headache, 2020. doi:

10.1111/head.13880.

[8] Wells RE, Strauss LD. The Value of Headache-Specific Recommendations During COVID-19[J]. Headache, 2020, 60(5): 820-823. doi: 10.1111/head.13821.

[9] Ali A. Delay in OnabotulinumtoxinA Treatment During the COVID-19 Pandemic-Perspectives from a Virus Hotspot[J]. Headache, 2020, 60(6): 1183-1186. doi: 10.1111/head.13830.

[10] Bobker SM, Robbins MS. COVID19 and Headache: A Primer for Trainees[J]. Headache, 2020. doi: 10.1111/head.13884.

[11] MaassenVanDenBrink A, de Vries T, Danser AHJ. Headache medication and the COVID-19 pandemic[J]. J Headache Pain, 2020, 21(1): 38. doi: 10.1186/s10194-020-01106-5.

[12] Bastien $\mathrm{CH}$, Vallières A, Morin CM. Validation of the Insomnia Severity Index as an outcome measure for insomnia research[J]. Sleep Med, 2001, 2(4): 297-307. doi: 10.1016/s1389-9457(00)00065-4. 
[13] Maroufizadeh S, Omani-Samani R, Almasi-Hashiani A, et al. The reliability and validity of the Patient Health Questionnaire-9 (PHQ-9) and PHQ-2 in patients with infertility[J]. Reprod Health. 2019, 16(1): 137. doi: 10.1186/s12978-019-0802-x.

[14] Wang C, Pan R, Wan X, et al. Immediate Psychological Responses and Associated Factors during the Initial Stage of the 2019 Coronavirus Disease (COVID-19) Epidemic among the General Population in China[J]. Int J Environ Res Public Health, 2020, 17(5): 1729. doi: 10.3390/ijerph17051729.

[15] Headache Classification Committee of the International Headache Society. Classification and diagnostic criteria for headache disorders, cranial neuralgias

and facial pain. Cephalalgia. 1988, 8(suppl 7): 1-96.

[16] Yu S, Liu R, Zhao G, et al. The Prevalence and Burden of Primary Headaches in China: A PopulationBased Door-to-Door Survey[J]. Headache, 2012, 52(4): 582-91. doi: 10.1111/j.1526-4610.2011.02061.x.

[17] Papetti L, Capuano A, Tarantino S, et al. Headache as an Emergency in Children and Adolescents[J]. Curr Pain Headache Rep, 2015, 19(3): 3. doi: 10.1007/s11916-015-0480-5.

[18] Antonaci F, Voiticovschi-losob C, Di Stefano AL, et al. The evolution of headache from childhood to adulthood: a review of the literature[J]. J Headache Pain, 2014, 15(1): 15. doi: 10.1186/1129-2377-15-15.

[19] Wöber-Bingöl C. Epidemiology of Migraine and Headache in Children and Adolescents[J]. Curr Pain Headache Rep, 2013, 17(6): 341. doi: 10.1007/s11916-013-0341-z.

[20] Wöber C, Brannath W, Schmidt K, et al. Prospective analysis of factors related to migraine attacks: the PAMINA study[J]. Cephalalgia, 2007, 27(4): 304-14. doi: 10.1111/j.1468-2982.2007.01279.x.

[21] de Bloom J, Kompier M, Geurts S, et al. Do we recover from vacation? Meta-analysis of vacation effects on health and well-being[J]. J Occup Health, 2009, 51(1): 13-25. doi: 10.1539/joh.k8004.

[22] Spierings EL, Ranke AH, Honkoop PC. Precipitating and Aggravating Factors of Migraine Versus Tension-type Headache[J]. Headache, 2001, 41(6): 554-8. doi: 10.1046/j.1526-4610.2001.041006554.x.

[23] Walter S. Lifestyle Behaviors and IIIness-Related Factors as Predictors of Recurrent Headache in U.S. Adolescents[J]. J Neurosci Nurs, 2014, 46(6): 337-50. doi: 10.1097/JNN.0000000000000095.

[24] Mohammadi S, Zandieh S, Dehghani M, et al. The buffering effect of family functioning on the psychological consequences of headache[J]. Psychol Health Med, 2017, 22(2): 237-243. doi: 10.1080/13548506.2016.1147054.

[25] Scher Al, Stewart WF, Ricci JA, et al. Factors associated with the onset and remission of chronic daily headache in a population-based study[J]. Pain, 2003, 106(1-2): 81-9. doi: 10.1016/s0304-3959(03)002938. 
[26] Wang Y, Xie J, Yang F, et al. The prevalence of primary headache disorders and their associated factors among nursing staff in North China[J]. J Headache Pain, 2015, 16: 4. doi: 10.1186/1129-2377-164.

[27] Xu X, Sun J, Nie S, et al. Seroprevalence of immunoglobulin M and Gantibodies against SARS-CoV-2 in China[J]. Nat Med, 2020, 26(8): 1193-1195. doi: 10.1038/s41591-020-0949-6.

\section{Tables}

Table 1 Comparison of headache intensity, headache days per month, and headache duration at baseline and during COVID-19

\begin{tabular}{|llll|}
\hline variables & Baseline & During COVID-19 & P value \\
\hline Headache severity & $4.290 \pm 1.680$ & $4.110 \pm 1.609$ & $\mathbf{0 . 0 0 0}$ \\
\hline Headache duration $(\mathrm{h})$ & $4.033 \pm 7.325$ & $3.414 \pm 6.859$ & $\mathbf{0 . 0 0 0}$ \\
\hline Headache days per month & $2.092 \pm 3.694$ & $1.788 \pm 2.989$ & $\mathbf{0 . 0 0 0}$ \\
\hline
\end{tabular}

Table 2 Comparison of demographic characteristics for the remission group, unchanged group and aggravating group according to headache duration 


\begin{tabular}{|c|c|c|c|c|c|c|c|}
\hline \multirow[t]{2}{*}{ characteristics } & \multirow{2}{*}{$\begin{array}{l}\text { The } \\
\text { remission } \\
\text { group }^{1} \\
(\mathrm{n}=686)\end{array}$} & \multirow{2}{*}{$\begin{array}{l}\text { The } \\
\text { unchanged } \\
\text { group } 2 \\
(n=1936)\end{array}$} & \multirow{2}{*}{$\begin{array}{l}\text { The } \\
\text { aggravating } \\
\text { group }{ }^{3} \\
(n=184)\end{array}$} & \multirow{2}{*}{$\begin{array}{l}\mathrm{P} \\
\text { value }\end{array}$} & \multicolumn{3}{|c|}{ P value Post hoc } \\
\hline & & & & & $\begin{array}{l}1 \text { vs } \\
2\end{array}$ & $\begin{array}{l}1 \text { vs } \\
3\end{array}$ & $\begin{array}{l}2 \text { vs } \\
3\end{array}$ \\
\hline Male, n (\%) & $\begin{array}{l}251 \\
\text { 『36.59】 }\end{array}$ & $715 \llbracket 36.93 \rrbracket$ & $77 \rrbracket 44.85 \rrbracket$ & 0.393 & & & \\
\hline Age, n (\%) & & & & 0.253 & & & \\
\hline$<30$ & $\begin{array}{l}176 \\
\otimes 25.66 \rrbracket\end{array}$ & $441 \rrbracket 22.78 \rrbracket$ & $53 \rrbracket 28.80 \rrbracket$ & & & & \\
\hline $30-50$ & 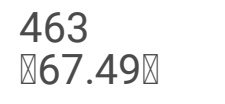 & 1371ه70.82】 & $120 \rrbracket 65.22 \rrbracket$ & & & & \\
\hline$>50$ & $47 \rrbracket 6.85 \rrbracket$ & $124 \rrbracket 6.40 \rrbracket$ & $11 \otimes 5.98 \rrbracket$ & & & & \\
\hline $\begin{array}{l}\text { Education } \\
\text { level, n (\%) }\end{array}$ & & & & 0.035 & 0.152 & 0.172 & 0.018 \\
\hline $\begin{array}{l}\text { junior } \\
\text { colleague or } \\
\text { lower }\end{array}$ & 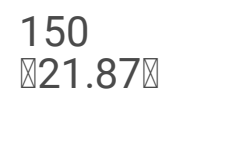 & $374(19.32)$ & $49(26.63)$ & & & & \\
\hline $\begin{array}{l}\text { University or } \\
\text { above }\end{array}$ & $\begin{array}{l}536 \\
\otimes 78.13 \rrbracket\end{array}$ & 1562(80.68) & 135(73.37) & & & & \\
\hline $\begin{array}{l}\text { Chronic } \\
\text { disease history, } \\
\text { n (\%) }\end{array}$ & 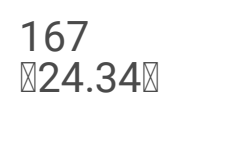 & $444 \rrbracket 22.93 \rrbracket$ & $52 \rrbracket 28.26 \rrbracket$ & 0.253 & & & \\
\hline Smoking, n (\%) & $91 \otimes 13.27 \rrbracket$ & $334 \rrbracket 17.25 \rrbracket$ & $47 \rrbracket 25.54 \rrbracket$ & 0.000 & 0.015 & 0.000 & 0.005 \\
\hline Drinking, n (\%) & $\begin{array}{l}279 \\
\square 40.67 \rrbracket\end{array}$ & 813ه41.99ه & 88\47.83\ & 0.217 & & & \\
\hline $\begin{array}{l}\text { Living in } \\
\text { Wuhan, } \mathrm{n}(\%)\end{array}$ & $20 \rrbracket 2.92 \rrbracket$ & $63 \rrbracket 3.25 \rrbracket$ & 13凶7.07》 & 0.018 & 0.663 & 0.009 & 0.008 \\
\hline $\begin{array}{l}\text { Having COVID- } \\
19 \text { symptoms } \\
\text { or }\end{array}$ & $45 \rrbracket 6.56 \rrbracket$ & 86『4.44『 & $20 \otimes 10.87 \rrbracket$ & 0.000 & 0.029 & 0.048 & 0.000 \\
\hline \multicolumn{8}{|l|}{$\begin{array}{l}\text { COVID-19 } \\
\text { diagnosis, n } \\
\text { (\%) }\end{array}$} \\
\hline $\begin{array}{l}\text { Having relative } \\
\text { or } \\
\text { acquaintance } \\
\text { got }\end{array}$ & $80 \otimes 11.66 \rrbracket$ & $240 \otimes 12.40 \rrbracket$ & $38 \rrbracket 20.65 \rrbracket$ & 0.004 & 0.613 & 0.002 & 0.002 \\
\hline \multicolumn{8}{|l|}{$\begin{array}{l}\text { COVID-19, n } \\
\text { (\%) }\end{array}$} \\
\hline $\begin{array}{l}\text { Getting support } \\
\text { from family }\end{array}$ & & & & 0.001 & 0.015 & 0.000 & 0.005 \\
\hline
\end{tabular}




\begin{tabular}{|c|c|c|c|c|c|c|c|}
\hline $\begin{array}{l}\text { Unchanged or } \\
\text { more }\end{array}$ & $\begin{array}{l}659 \\
(96.06)\end{array}$ & $\begin{array}{l}1811 \\
(93.54)\end{array}$ & 163 (88.59) & & & & \\
\hline Less & $27 \rrbracket 3.94 \rrbracket$ & 125ه6.46ه & 21ه11.41ه & & & & \\
\hline $\begin{array}{l}\text { Getting support } \\
\text { from the } \\
\text { outside world, } \\
\text { n (\%) }\end{array}$ & & & & 0.028 & 0.056 & 0.011 & 0.120 \\
\hline $\begin{array}{l}\text { Unchanged or } \\
\text { more }\end{array}$ & $\begin{array}{l}599 \\
(87.32)\end{array}$ & $\begin{array}{l}1632 \\
(84.30)\end{array}$ & $147(79.89)$ & & & & \\
\hline Less & 87囚12.68】 & $304 \otimes 15.70 \bigotimes$ & $37 \rrbracket 20.11 \rrbracket$ & & & & \\
\hline ISI score & $\begin{array}{l}6.70 \pm \\
5.30\end{array}$ & $8.16 \pm 5.67$ & $10.22 \pm 6.01$ & 0.000 & 0.000 & 0.000 & 0.000 \\
\hline PHQ9 score & $\begin{array}{l}5.99 \pm \\
4.74\end{array}$ & $6.92 \pm 4.93$ & $8.74 \pm 4.89$ & 0.000 & 0.000 & 0.000 & 0.000 \\
\hline ISER score & $\begin{array}{l}17.99 \pm \\
14.18\end{array}$ & $\begin{array}{l}21.08 \pm \\
14.63\end{array}$ & $\begin{array}{l}27.71 \pm \\
16.96\end{array}$ & 0.000 & 0.000 & 0.000 & 0.000 \\
\hline
\end{tabular}

Table 3 Comparison of demographic characteristics for the remission group, unchanged group and aggravating group according to headache frequency. 


\begin{tabular}{|c|c|c|c|c|c|c|c|}
\hline \multirow[t]{2}{*}{ characteristics } & \multirow{2}{*}{$\begin{array}{l}\text { The } \\
\text { remission } \\
\text { group } 1 \\
(n=737)\end{array}$} & \multirow{2}{*}{$\begin{array}{l}\text { The } \\
\text { unchanged } \\
\text { group } 2 \\
(n=1790)\end{array}$} & \multirow{2}{*}{$\begin{array}{l}\text { The } \\
\text { aggravating } \\
\text { group } \\
(\mathrm{n}=279)\end{array}$} & \multirow{2}{*}{$\begin{array}{l}\mathrm{P} \\
\text { value }\end{array}$} & \multicolumn{3}{|c|}{$\mathrm{P}$ value Post hoc } \\
\hline & & & & & $\begin{array}{l}1 \mathrm{vs} \\
2\end{array}$ & 1 vs 3 & $\begin{array}{l}2 \mathrm{vs} \\
3\end{array}$ \\
\hline Male, n (\%) & $\begin{array}{l}289 \\
\bigotimes 39.21 \rrbracket\end{array}$ & $633 \rrbracket 35.36 \rrbracket$ & $21 \rrbracket 43.47 \rrbracket$ & 0.015 & 0.068 & 0.228 & 0.010 \\
\hline Age, n (\%) & & & & 0.431 & & & \\
\hline$<30$ & 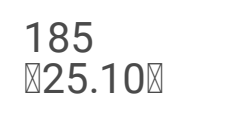 & 410ه22.91】 & $75 \llbracket 26.88 \rrbracket$ & & & & \\
\hline $30-50$ & $\begin{array}{l}502 \\
₫ 68.11 \rrbracket\end{array}$ & $\begin{array}{l}1263 \\
\otimes 70.56 \rrbracket\end{array}$ & 190囚68.10囚 & & & & \\
\hline$>50$ & $50 \otimes 6.79 \rrbracket$ & 117ه6.53ه & $14 \bigotimes 7.82 \rrbracket$ & & & & \\
\hline $\begin{array}{l}\text { Education } \\
\text { level, n (\%) }\end{array}$ & & & & 0.260 & & & \\
\hline $\begin{array}{l}\text { junior } \\
\text { colleague or } \\
\text { lower }\end{array}$ & 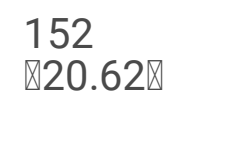 & $354(19.78)$ & $64(24.01)$ & & & & \\
\hline $\begin{array}{l}\text { University or } \\
\text { above }\end{array}$ & $\begin{array}{l}585 \\
\square 79.38 \rrbracket\end{array}$ & 1456(80.22) & $212(75.99)$ & & & & \\
\hline $\begin{array}{l}\text { Chronic } \\
\text { disease } \\
\text { history, n (\%) }\end{array}$ & $\begin{array}{l}184 \\
\square 24.97 \rrbracket\end{array}$ & $385 \llbracket 21.51 \rrbracket$ & $94 \llbracket 33.69 \rrbracket$ & 0.000 & 0.059 & 0.005 & 0.000 \\
\hline $\begin{array}{l}\text { Smoking, n } \\
\text { (\%) }\end{array}$ & 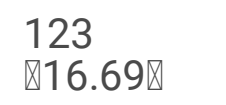 & 291ه16.26》 & $58 \llbracket 20.79 \rrbracket$ & 0.169 & & & \\
\hline Drinking, n (\%) & 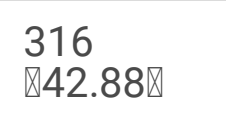 & $725 \llbracket 40.50 \rrbracket$ & 139ه49.82》 & 0.012 & 0.270 & 0.047 & 0.003 \\
\hline $\begin{array}{l}\text { Living in } \\
\text { Wuhan, } \mathrm{n}(\%)\end{array}$ & $18 \rrbracket 2.44 \rrbracket$ & $59 \rrbracket 3.30 \rrbracket$ & 19ه6.81ه & 0.003 & 0.256 & 0.001 & 0.004 \\
\hline $\begin{array}{l}\text { Having } \\
\text { COVID-19 } \\
\text { symptoms or }\end{array}$ & $41 \rrbracket 5.56 \rrbracket$ & $75 \rrbracket 4.19 \rrbracket$ & $35 \rrbracket 12.54 \rrbracket$ & 0.000 & 0.134 & 0.000 & 0.000 \\
\hline $\begin{array}{l}\text { CoVID-19 } \\
\text { diagnosis, n } \\
\text { (\%) }\end{array}$ & & & & & & & \\
\hline $\begin{array}{l}\text { Having } \\
\text { relative or } \\
\text { acquaintance } \\
\text { got }\end{array}$ & $\begin{array}{l}90 \\
\square 12.31 \rrbracket\end{array}$ & $202 \otimes 11.28 \rrbracket$ & 66ه23.66】 & 0.000 & 0.508 & 0.000 & 0.000 \\
\hline $\begin{array}{l}\text { COVID-19, n } \\
(\%)\end{array}$ & & & & & & & \\
\hline Getting & & & & 0.027 & 0.407 & 0.071 & 0.007 \\
\hline
\end{tabular}




\begin{tabular}{|c|c|c|c|c|c|c|c|}
\hline $\begin{array}{l}\text { Unchanged or } \\
\text { more }\end{array}$ & $\begin{array}{l}690 \\
(93.62)\end{array}$ & $\begin{array}{l}1691 \\
(94.47)\end{array}$ & $252(90.32)$ & & & & \\
\hline Less & 47囚6.38囚 & $99 \llbracket 5.53 \rrbracket$ & 27ه9.68》 & & & & \\
\hline $\begin{array}{l}\text { Getting } \\
\text { support from } \\
\text { the outside } \\
\text { world, n (\%) }\end{array}$ & & & & 0.258 & & & \\
\hline $\begin{array}{l}\text { Unchanged or } \\
\text { more }\end{array}$ & $\begin{array}{l}635 \\
(86.16)\end{array}$ & $\begin{array}{l}1514 \\
(84.58)\end{array}$ & 229 (82.08) & & & & \\
\hline Less & 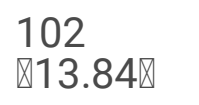 & 276ه15.42》 & $50 \rrbracket 17.92 \rrbracket$ & & & & \\
\hline ISI score & $\begin{array}{l}6.99 \pm \\
5.48\end{array}$ & $8.25 \pm 5.66$ & $8.42 \pm 5.93$ & 0.000 & 0.000 & 0.000 & 1.000 \\
\hline PHQ9 score & $\begin{array}{l}6.18 \pm \\
4.84\end{array}$ & $7.00 \pm 4.88$ & $7.28 \pm 5.27$ & 0.000 & 0.000 & 0.006 & 1.000 \\
\hline ISER score & $\begin{array}{l}18.79 \pm \\
14.83\end{array}$ & $\begin{array}{l}21.32 \pm \\
14.57\end{array}$ & $\begin{array}{l}22.36 \pm \\
16.25\end{array}$ & 0.000 & 0.000 & 0.002 & 1.000 \\
\hline
\end{tabular}

Table 4 Comparison of demographic characteristics for the remission group, unchanged group and aggravating group according to headache intensity. 


\begin{tabular}{|c|c|c|c|c|c|c|c|}
\hline \multirow[t]{2}{*}{ characteristics } & \multirow{2}{*}{$\begin{array}{l}\text { The } \\
\text { remission } \\
\text { group }{ }^{1} \\
(n=258)\end{array}$} & \multirow{2}{*}{$\begin{array}{l}\text { The } \\
\text { unchanged } \\
\text { group } 2 \\
(n=2451)\end{array}$} & \multirow{2}{*}{$\begin{array}{l}\text { The } \\
\text { aggravating } \\
\text { group } \\
(n=97)\end{array}$} & \multirow{2}{*}{$\begin{array}{l}P \\
\text { value }\end{array}$} & \multicolumn{3}{|c|}{ P value Post hoc } \\
\hline & & & & & $\begin{array}{l}1 \text { vs } \\
2\end{array}$ & $\begin{array}{l}1 \text { vs } \\
3\end{array}$ & $\begin{array}{l}2 \text { vs } \\
3\end{array}$ \\
\hline Male, n (\%) & 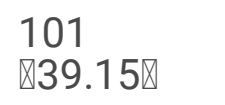 & $901 \rrbracket 36.76 \rrbracket$ & $41 \rrbracket 42.27 \rrbracket$ & 0.430 & & & \\
\hline Age, n (\%) & & & & 0.047 & & & \\
\hline$<30$ & $77 \rrbracket 29.84 \rrbracket$ & $563 \rrbracket 22.97 \rrbracket$ & $30 \rrbracket 30.93 \rrbracket$ & & & & \\
\hline $30-50$ & 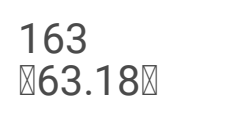 & 1731ه70.62》 & $60 \rrbracket 61.86 \rrbracket$ & & & & \\
\hline$>50$ & $18 \rrbracket 6.98 \rrbracket$ & 157ه6.41》 & $7 \rrbracket 7.21 \rrbracket$ & & & & \\
\hline $\begin{array}{l}\text { Education } \\
\text { level, n (\%) }\end{array}$ & & & & 0.019 & 0.005 & 0.209 & 0.825 \\
\hline $\begin{array}{l}\text { junior } \\
\text { colleague or } \\
\text { lower }\end{array}$ & $70 \rrbracket 27.13 \rrbracket$ & 483(19.71) & $20(20.62)$ & & & & \\
\hline $\begin{array}{l}\text { University or } \\
\text { above }\end{array}$ & $\begin{array}{l}188 \\
\square 72.87 \rrbracket\end{array}$ & 1968(80.29) & 77(79.38) & & & & \\
\hline $\begin{array}{l}\text { Chronic } \\
\text { disease history, } \\
\text { n (\%) }\end{array}$ & $68 \rrbracket 26.36 \rrbracket$ & $567 \rrbracket 23.13 \rrbracket$ & $28 \llbracket 28.87 \rrbracket$ & 0.238 & & & \\
\hline Smoking, n (\%) & $53 \llbracket 20.54 \rrbracket$ & $398 \rrbracket 16.24 \rrbracket$ & $21 \rrbracket 21.65 \rrbracket$ & 0.000 & 0.000 & 0.000 & 0.083 \\
\hline Drinking, n (\%) & 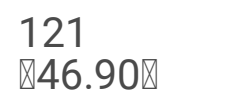 & 1010ه41.21区 & $49 ه 50.52 \rrbracket$ & 0.048 & 0.078 & 0.543 & 0.068 \\
\hline $\begin{array}{l}\text { Living in } \\
\text { Wuhan, } \mathrm{n}(\%)\end{array}$ & $11 \rrbracket 4.26 \rrbracket$ & $77 \rrbracket 3.14 \rrbracket$ & $8 \rrbracket 8.25 \rrbracket$ & 0.019 & 0.334 & 0.137 & 0.006 \\
\hline $\begin{array}{l}\text { Having COVID- } \\
19 \text { symptoms } \\
\text { or } \\
\text { CoVID-19 } \\
\text { diagnosis, n } \\
(\%)\end{array}$ & $20 \rrbracket 7.75 \rrbracket$ & 121ه4.94】 & $10 \otimes 10.31 \rrbracket$ & 0.015 & 0.053 & 0.440 & 0.030 \\
\hline $\begin{array}{l}\text { Having relative } \\
\text { or } \\
\text { acquaintance } \\
\text { got } \\
\text { coVID-19, n } \\
\text { (\%) }\end{array}$ & $47 \rrbracket 18.22 \rrbracket$ & 276ه11.26ه & $35 \rrbracket 36.08 \rrbracket$ & 0.000 & 0.001 & 0.000 & 0.000 \\
\hline $\begin{array}{l}\text { Getting support } \\
\text { from family } \\
\text { members, } n(\%)\end{array}$ & & & & 0.002 & 0.060 & 0.170 & 0.001 \\
\hline
\end{tabular}




\begin{tabular}{|c|c|c|c|c|c|c|c|}
\hline $\begin{array}{l}\text { Unchanged or } \\
\text { more }\end{array}$ & $\begin{array}{l}236 \\
(91.47)\end{array}$ & 2313 (94.37) & $84(86.60)$ & & & & \\
\hline Less & 22ख8.53囚 & 138ه5.63囚 & 13囚13.40囚 & & & & \\
\hline $\begin{array}{l}\text { Getting support } \\
\text { from the } \\
\text { outside world, } \\
\text { n (\%) }\end{array}$ & & & & 0.112 & & & \\
\hline $\begin{array}{l}\text { Unchanged or } \\
\text { more }\end{array}$ & $\begin{array}{l}221 \\
(85.66)\end{array}$ & $2082(84.94)$ & 75 (77.32) & & & & \\
\hline Less & $37 \rrbracket 14.34 \rrbracket$ & 369ه15.06ه & $22 \rrbracket 22.68 \rrbracket$ & & & & \\
\hline ISI score & $\begin{array}{l}7.52 \pm \\
5.57\end{array}$ & $8.04 \pm 5.68$ & $6.50 \pm 5.44$ & 0.009 & 0.494 & 0.225 & 0.014 \\
\hline PHQ9 score & $\begin{array}{l}6.83 \pm \\
5.34\end{array}$ & $6.85 \pm 4.90$ & $5.80 \pm 4.38$ & 0.110 & & & \\
\hline ISER score & $\begin{array}{l}20.82 \pm \\
15.42\end{array}$ & $\begin{array}{l}20.86 \pm \\
14.85\end{array}$ & $\begin{array}{l}18.03 \pm \\
13.39\end{array}$ & 0.294 & & & \\
\hline
\end{tabular}

Table 5 Predictors of remission in headache duration.

\begin{tabular}{|c|c|c|}
\hline Variables & OR $(95 \% \mathrm{Cl})$ & $P$ value \\
\hline Smoking ${ }^{1}$ & $1.397(1.090-1.790)$ & 0.008 \\
\hline Getting support from family members ${ }^{2}$ & $1.656(1.075-2.550)$ & 0.022 \\
\hline Getting support from the outside world ${ }^{3}$ & $1.218(0.938-1.580)$ & 0.139 \\
\hline ISI score & $1.013(0.992-1.034)$ & 0.232 \\
\hline PHQ9 score & $1.006(0.982-1.031)$ & 0.619 \\
\hline ISER score & $1.009(1.002-1.016)$ & 0.016 \\
\hline
\end{tabular}

1, non-smoking vs smoking;

2, Getting Unchanged or more support from family members vs Getting less support from family members;

3, Getting Unchanged or more support from the outside world vs Getting less support from family members. 
Table 6 Predictors of remission in headache frequency

\begin{tabular}{|lll|}
\hline Variables & OR $(95 \% \mathrm{Cl})$ & P value \\
\hline ISI score & $0.968(0.948-0.989)$ & $\mathbf{0 . 0 0 3}$ \\
\hline PHQ9 score & $0.997(0.973-1.022)$ & 0.809 \\
\hline ISER score & $0.994(0.987-1.002)$ & 0.131 \\
\hline
\end{tabular}

Table 7 Predictors of remission in headache intensity

\begin{tabular}{|lll|}
\hline Variables & OR $(95 \% \mathrm{Cl})$ & P value \\
\hline Having relative or acquaintance & $0.643(0.458-0.902)$ & $\mathbf{0 . 0 1 1}$ \\
got COVID-191 & & \\
\hline Education level $^{3}$ & $1.478(1.103-1.980)$ & $\mathbf{0 . 0 0 9}$ \\
\hline
\end{tabular}

1, Not having relative or acquaintance got COVID-19 vs having relative or acquaintance got COVID-19;

2, junior colleague or lower vs University or above.

\section{Figures}

A

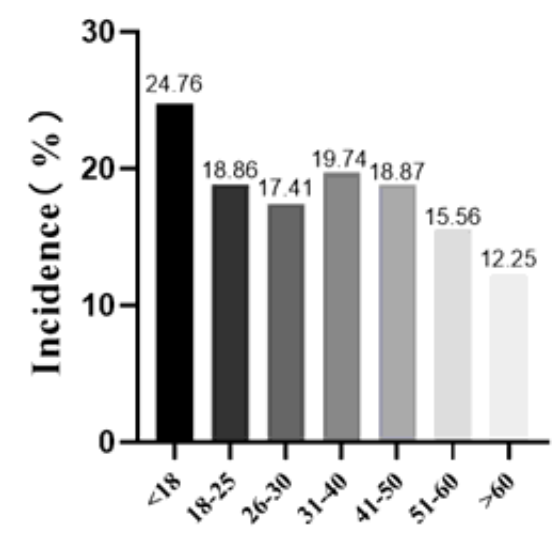

B

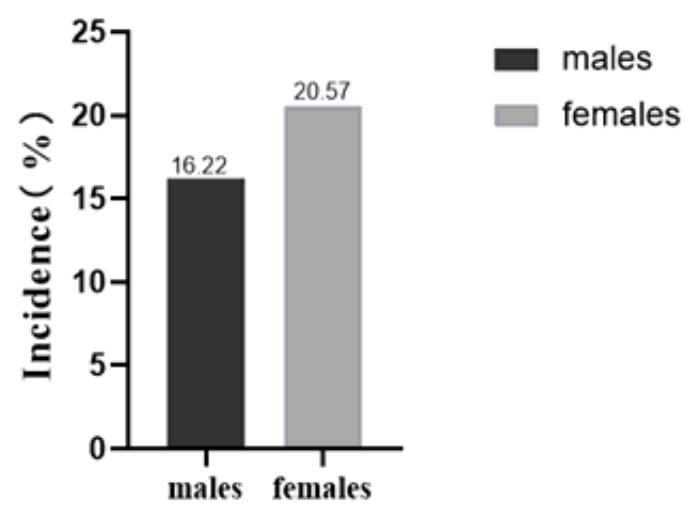

\section{Figure 1}

Basic demographic features of all headaches. 
A

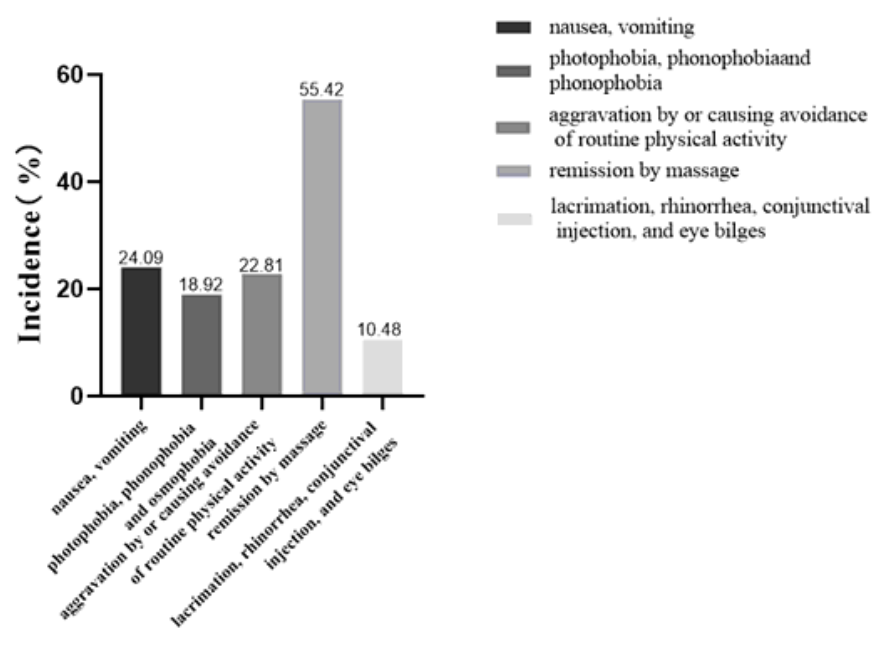

B

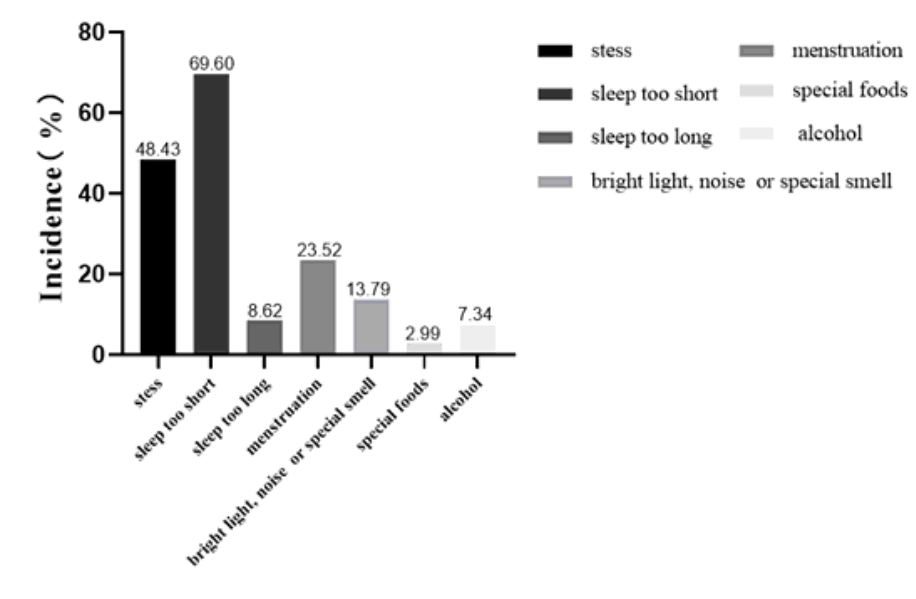

Figure 2

Characteristics of accompanying symptoms and headache triggers.

A

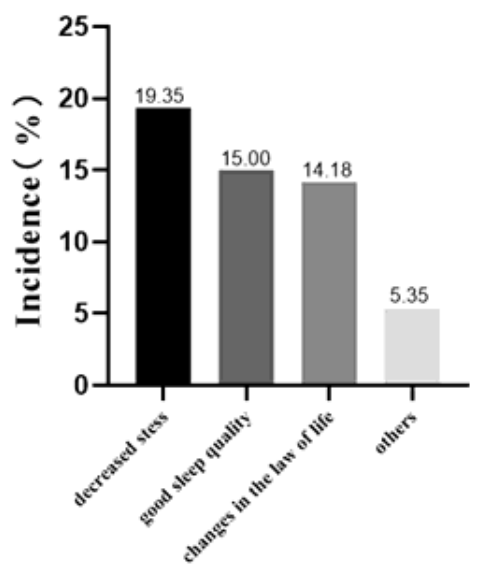

B

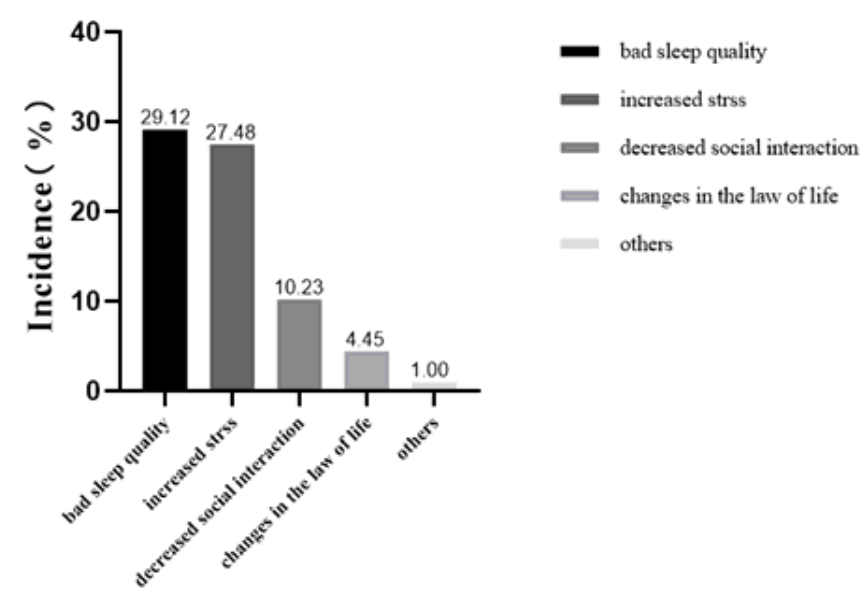

Figure 3

Self-reported factors associated with remission (A) or deterioration (B) in headache during COVID-19. 


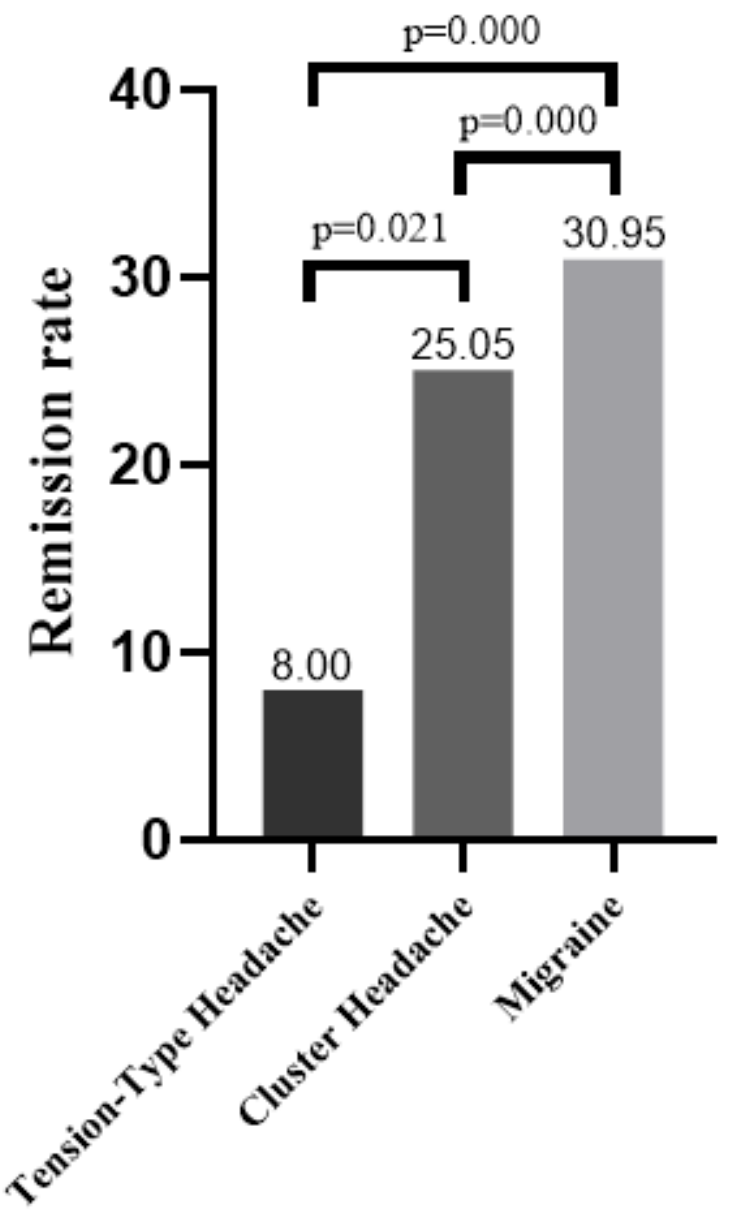

Tension-Type Headache

Cluster Headache

Migraine

Figure 4

Remission rate of headache duration among $\mathrm{TTH}$, migraine and $\mathrm{CH}$. 
A

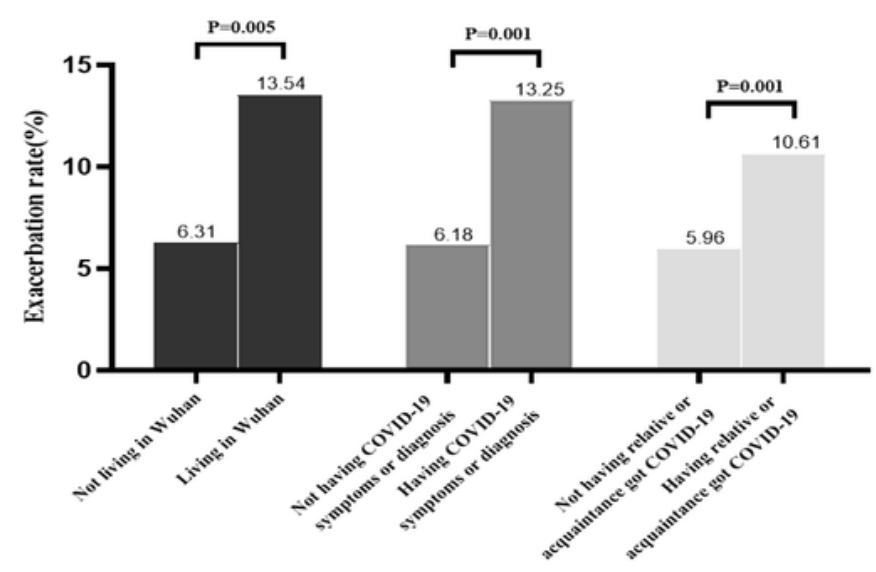

B

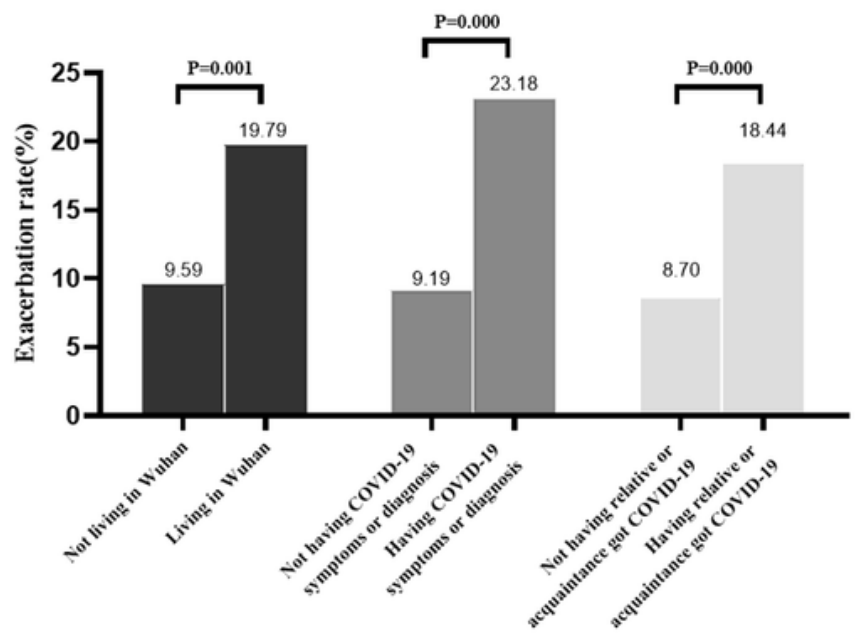

$\mathrm{C}$

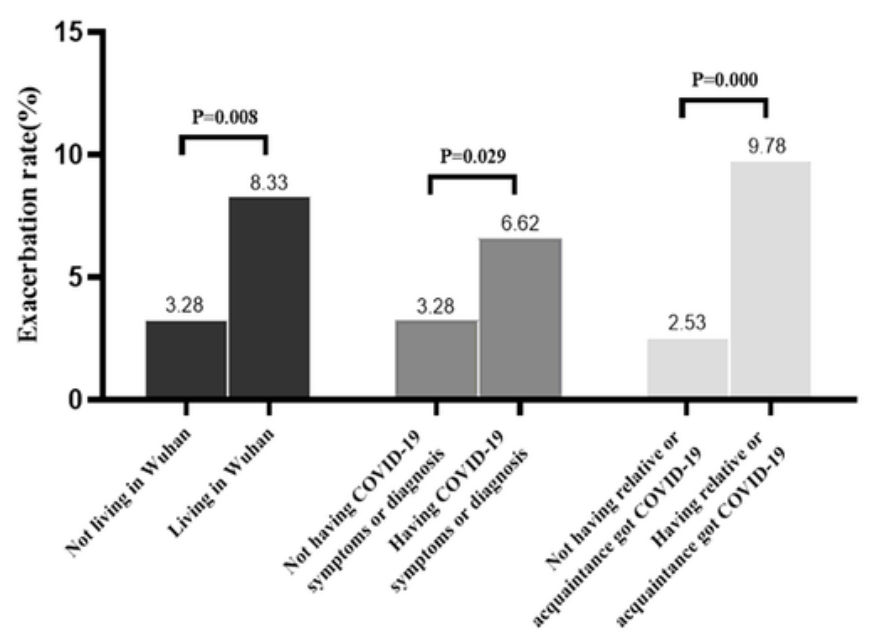

Figure 5

Exacerbation factors of headache duration (A), headache frequency $(B)$ and headache intensity (C). 